\title{
Penggunaan Akun Instagram sebagai Media Informasi Wisata Kuliner
}

\author{
Difa Nurhasna Ayutiani ${ }^{1} \&$ Berlian Primadani Satria Putri ${ }^{2}$ \\ ${ }^{1,2}$ Universitas Telkom
}

\begin{abstract}
ABSTRAK
Penelitian yang berjudul 'Penggunaan Akun Instagram sebagai Media Informasi Wisata Kuliner' bertujuan untuk mengetahui penggunaan akun Instagram@Kulinerbandung oleh followers-nya dalam menjadikan akun tersebut sebagai informasi kuliner berdasarkan respons kognitif, afektif dan behavioral menurut Steven M. Chaffee. Penelitian ini menggunakan pendekatan kualitatif dengan metode yang dilakukan adalah virtual etnografi. Kajian virtual etnografi ini adalah sebuah pola pendekatan penelitian terhadap Internet yang dilakukan tergantung bagaimana individu itu menanggapinya. Budaya yang terdapat di dalam sebuah Internet bisa diperluas dengan menggunakan perspektif etnografi melalui konstusi teknologi dalam konteks fenomena sosial budaya yang terkandung didalamnya. Fokus penelitian ini adalah untuk melihat bagaimana hasil atau perubahan respons kognitif, afektif dan behavioral dalam penggunaan akun Instagram @Kulinerbandung oleh followers-nya. Teknik pengumpulan data yang digunakan ialah wawancara offline dan online secara mendalam, observasi dan dokumentasi. Hasil penelitian ini adalah adanya perubahan dalam respons kognitif yaitu followers mendapatkan informasi dan manfaat yang didapatkan dari akun @Kulinerbandung. Setelah mendapatkan informasi dan manfaat, followers juga mengalami respons afektif yaitu adanya perubahan emosi atau perasaan setelah melihat postingan akun@Kulinerbandung, setelah merasakan respons afektif, munculah sebuah respons behavioral yaitu adanya tindakan berwisata kuliner dan memberikan informasi kembali setelah melihat postingan akun@Kulinerbandung.
\end{abstract}

Kata-kata Kunci: @Kulinerbandung; instagram; media informasi; respons; virtual etnografi

\section{The Uses of Instagram as Informative Media for Culinary Tour}

\begin{abstract}
The study, entitled 'The Uses Of Instagram As Informative Media For Culinary Tour have a purpose to ascertain the uses of Instagram account @Kulinerbandung by his followers in making these accounts as culinary information based on the responsse of cognitive, affective and behavioral according Steven M. Chaffee. This study, use a qualitative approach with methods that do are virtual ethnography. This study is a pattern of research approaches to the Internet that is done depending on how the individual individual responds. Culture that exists in an internet can be used by using ethnography perspective through technological constancy in context of social culture phenomenon contained in it. The focus of this study is to see how the results or changes in responsse to cognitive, affective and behavioral in the uses of Instagram account@Kulinerbandung by his followers.The data collected by using the offline and online in depth interviews, observation and documentation. Results of this study was the change in cognitive responsses that followers get information and benefits of @Kulinerbandung account. After getting the information and benefits, followers are also experiencing affective responsses are the change in emotions or feelings after viewing messages of @Kulinerbandung account, after feeling affective responsses, there are apear a behavioral responsse that is the act of a culinary tour, and provide information back after seeing the posts of @ Kulinerbandung account.
\end{abstract}

Keywords: @Kulinerbandung; ethnographic virtual; information media; Instagram; respond

Korespondensi: Difa Nurhasna Ayutiani. Universitas Telkom. Jl.Telekomunikasi No.01, Terusan Buah Batu, Sukapura, Dayeuhkolot, Bandung, Jawa Barat 40257.Email: difanrhasna@gmail.com 


\section{PENDAHULUAN}

Komunikasi merupakan hal paling penting dalam kehidupan manusia. Manusia sebagai makhluk sosial yang dihidupnya tidak bisa melepaskan diri dari pengaruh manusia bahkan mahluk lain, pasti berinteraksi dan bersosialisasi dengan cara berkomusikasi baik verbal maupun non-verbal. Saat ini komunikasi semakin mudah dengan adanya teknologi. Teknologi ini diciptakan untuk memudahkan kita dalam berkomunikasi dan mendapatkan informasi secara cepat. Salah satu teknologi komunikasi saat ini adalah Internet. Awal dekade 1990an teknologi Internet masih terbilang asing untuk sebagian besar masyarakat Indonesia. Saat itu, Internet hanya dapat diakses oleh segelintir orang karena untuk mengakses Internet dibutuhkan biaya yang tidak sedikit ditambah minimnya jumlah pengguna personal computer atau pc. Sejalan bergulirnya waktu, aksesibilitas teknologi Internet menjadi semakin luas dan mudah. Menurut data yang dilansir Asosiasi Penyelenggara Jasa Internet Indonesia (APJII), sampai awal tahun 2009 tercatat sekitar 25 juta pengguna Internet. Kedepannya angka ini akan meningkat tajam karena APJII menghitung bahwa pengguna Internet meningkat 25 persen per tahun. Sekarang teknologi informasi berkembang semakin cepat. Hampir sebagian besar dari kegiatan manusia memanfaatkan kecanggihan teknologi informasi. Perkembangan teknologi informasi memunculkan berbagai jenis kegiatan yang berbasis pada teknologi informasi, seperti e-government, e-commerce, e-education dan lainnya (Gumilar, \& Ipit Zulfan, 2014: 86).

Kehadiran Internet bisa dibilang terlambat di Indonesia, namun perkembangannya pun sangat cepat. Pada awalnya Internet hanya tersedia di media komputer, namun saat ini sudah ada di media elektronik yang kita bisa bawa kemana mana seperti tablet, laptop dan handphone. Saat ini media media konvensional seperti televisi, radio dan koran telah dikesampingkan oleh masyarakat di dunia, termasuk di Indonesia. Media konvensional ini telah tergantikan oleh Internet. Bahkan akses media konvensional saat ini sudah berbasis Internet. Bukti media konvensional telah tergantikan oleh media elektronik dan Internet terlihat dari survei dari We Are Social bahwa pengguna internet dapat menghabiskan rata-rata sekitar 4 jam 42 menit untuk mengakses Internet di PC atau tablet dalam sehari.

Dari data pada gambar 1 terlihat bahwa masyarakat Indonesia sangat mengikuti perkembangan media. Hal ini juga merupakan gaya hidup masyarakat Indonesia baik media elektronik, cetak maupun online. Salah satu bukti meningkatnya penggunaan media terutama media online adalah banyaknya 


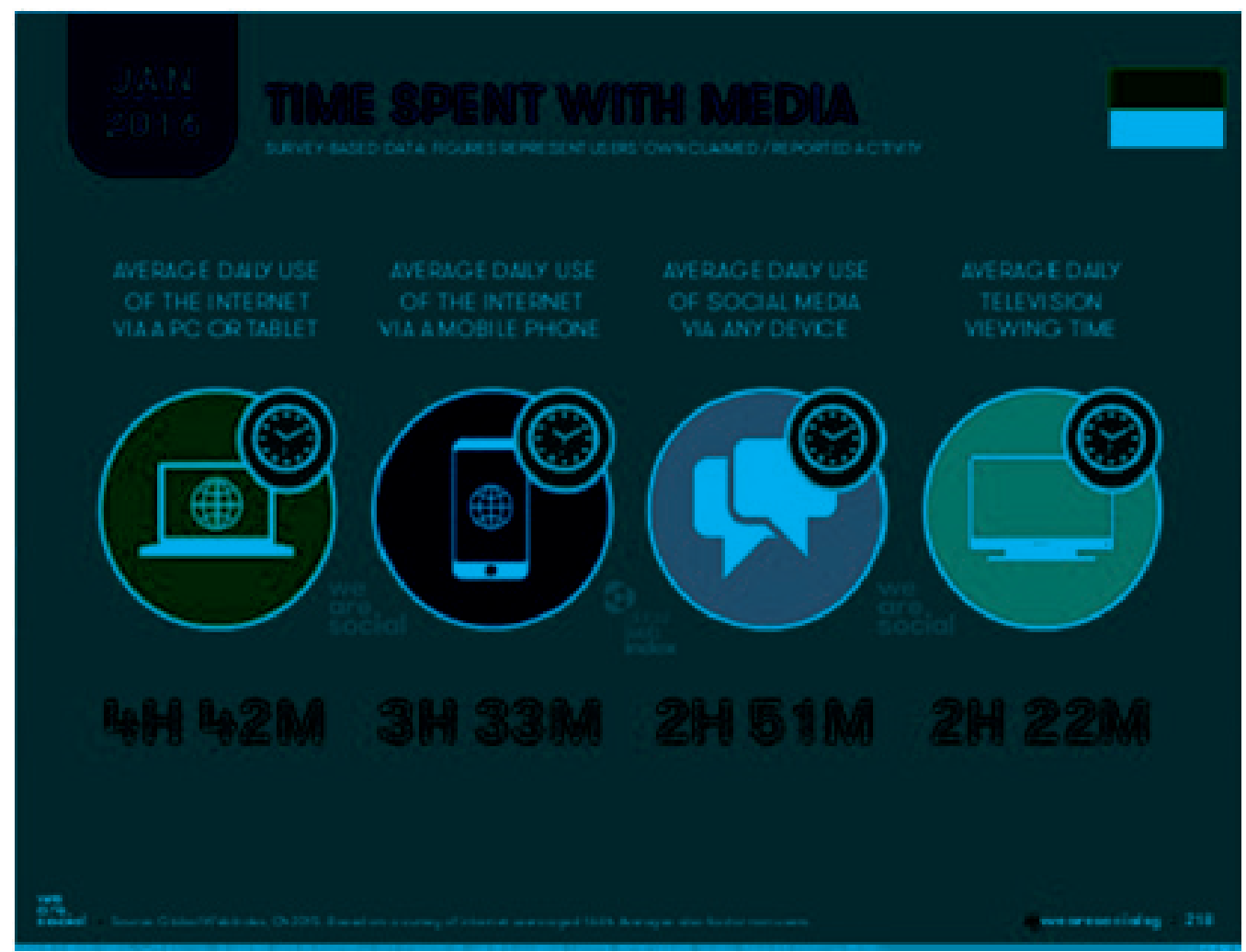

Sumber: wearesocial.com, 2016

\section{Gambar 1 Time Spent With Media In Indonesia}

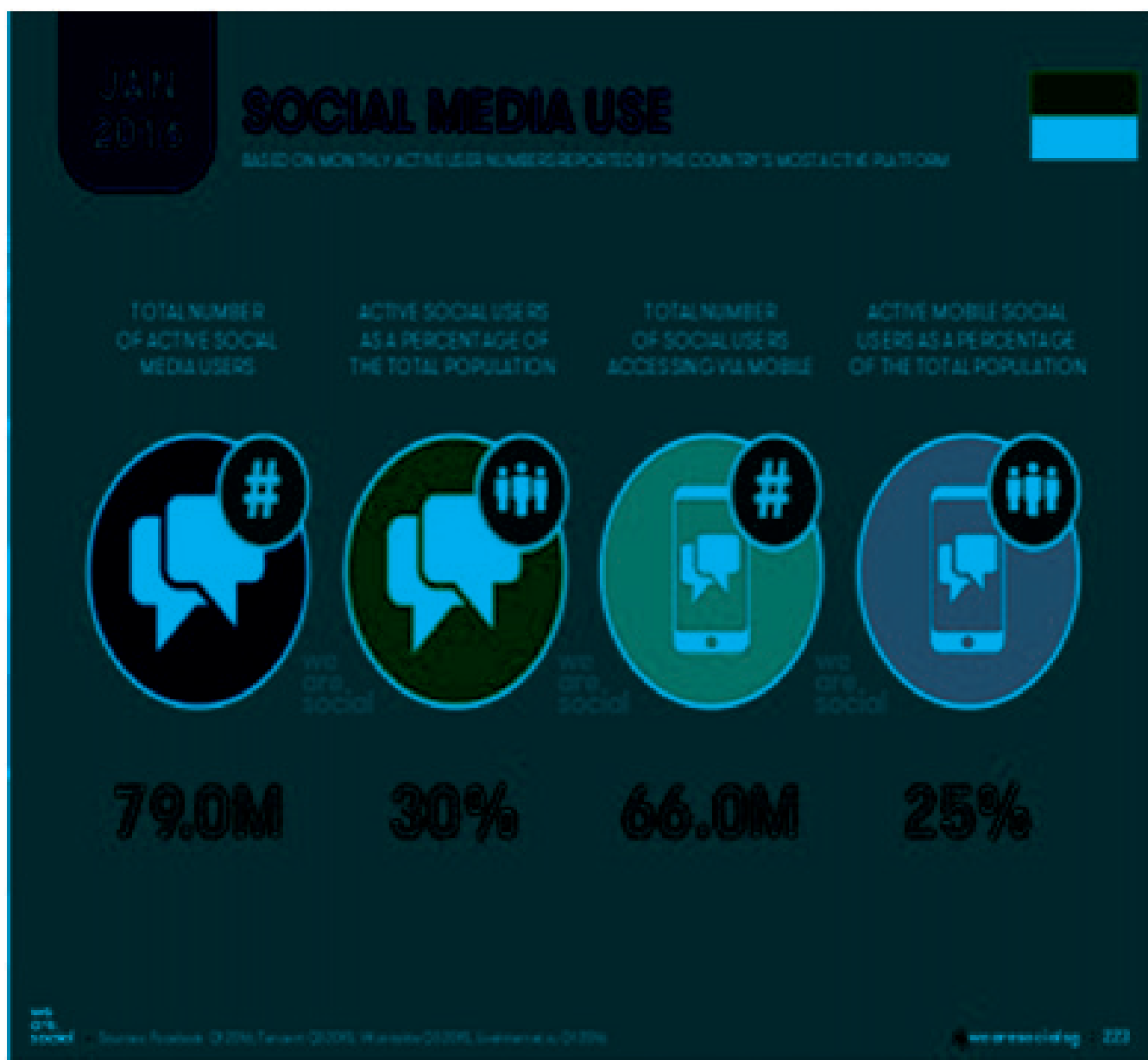

Sumber: wearesocial.com, 2016

Gambar 2 Social Media Use In Indonesia

Penggunaan Akun Instagram Sebagai Media Informasi Wisata Kuliner (Difa Nurhasna Ayutiani dan Berlian Primadani Satria Putri) 
pengguna Internet di dunia ini tak terkecuali di negara kita Indonesia. Saat ini pun media online khususnya media sosial telah berkembang pesat di Indonesia. Mmudahnya akses media sosial hanya dengan membuka gadget, kita dapat memperoleh banyak informasi dari segala penjuru dunia dalam media sosial memudahkan penggunanya dalam mandapatkan informasi yang sedang menjadi topik pembicaraan yang sedang mereka inginkan. Karena sesibuk apapun, mereka tetap membutuhkan informasi guna mempermudah pekerjaan mereka ataupun tujuan-tujuan lainnya seperti agar up to date, hiburan, edukasi dll.

Dengan jumlah pengguna aktif Internet sekitar 88,1 juta, cukup sebanding dengan jumlah pengguna media sosial saat ini. Dipaparkan We are Social, ada sekitar 79 juta pengguna aktif media sosial di Indonesia. Hal ini senada dengan apa yang dinyatakan oleh Putri dan Fithrah (2017) bahwa sejak tahun 2012, keterikatan masyarakat Indonesia terhadap media sosial semakin meningkat.

Dari data pada gambar 2 terlihat masyarakat Indonesia sangat senang mengakses media sosial. Media sosial adalah sebuah media yang digunakan untuk besosialisasi dengan masyarakat lain dengan menggunakan jaringan Internet. Media sosial saat ini digunakan juga untuk mencari informasi, bahkan beberapa

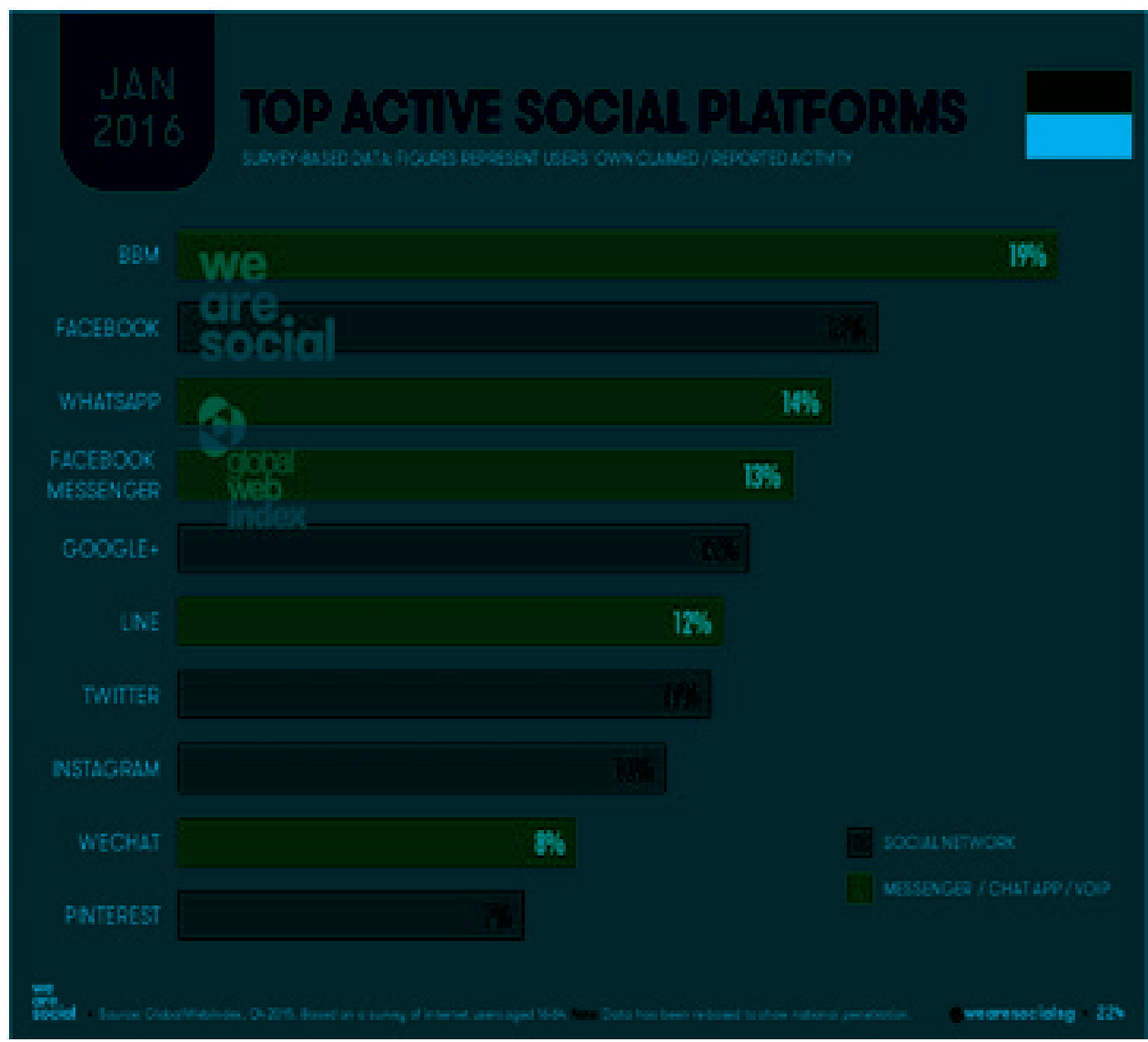

Sumber: wearesocial.com, 2016

Gambar 3 Top Active Social Platrorms In Indonesia 
media sosial telah mengadakan fitur khusus untuk berita. Berbagai macam media sosial tersebar dan digunakan di seluruh dunia, bahkan beberapa negara membuat media sosial khusus untuk negaranya tersebut.

Masyarakat Indonesia mengikuti perubahan media, terutama media online yaitu media sosial membuat mereka mendapatkan informasi secara cepat melalui berbagai macam akun di media sosial. Menurut wearesocial.com Instagram masuk ke dalam 10 aplikasi media sosial yang terpopuler digunakan di Indonesia.

Mudahnya cara penggunaan aplikasi Instagram membuat pengguna menjadikan Instagram sebagai media informasi untuk memenuhi kebutuhannya. Saat ini terdapat beberapa akun Instagram yang memberikan banyak informasi kepada penggunanya seperti akun make up tutorial, akun online shop, dan salah satu yang menarik adalah akun yang menyediakan informasi tentang wisata kuliner. Akun yang menyediakan informasi mengenai tempat-tempat kuliner ini sangat digemari oleh Instagrammers-Instagrammers di Indonesia karena keanekaragaman makanan nya dan merupakan salah satu tempat yang dijadikan referensi destinasi kuliner masyarakat Indonesia. Mengutip dari solopos.com, survei yang dilakukan tim Percepatan Pengembangan Destinasi Wisata Kuliner buatan Kementerian Pariwisata bekerja sama dengan sejumlah pihak yang berlangsung tanggal 3 September 2015-25 Oktober 2015 dengan pemilihan 10 kota destinasi wisata kuliner oleh 13 ahli kuliner yang hasilnya menunjukkan bahwa kota Bandung dan kota Solo menjadi urutan teratas di Indonesia soal wisata Kuliner. Tabel 1 adalah tiga aspek yang dilihat oleh Kemenpar.

\section{Tabel 1 Skala Kota Wisata Kuliner di Indonesia}

\begin{tabular}{clcc}
\hline No & \multicolumn{1}{c}{ Aspek } & Skala Kota Bandung (1-100) & Skala Kota Solo (1-100) \\
\hline 1 & $\begin{array}{l}\text { Destinasi Kuliner Terbaik di } \\
\text { Indonesia }\end{array}$ & 83 & 83 \\
2 & $\begin{array}{l}\text { Peran Pemerintah } \\
\text { Mendukung Perkembangan }\end{array}$ & 91 & 79 \\
& $\begin{array}{l}\text { Destinasi Wisata Kuliner } \\
\text { Kelayakan Produk dan Daya }\end{array}$ & (Tidak diketahui, tetapi kota & (Tidak diketahui, tetapi kota \\
& $\begin{array}{l}\text { Tarik Wisata, Kelayakan } \\
\text { Pelayanan dan Kelayakan }\end{array}$ & Bandung skalanya lebih & Solo lebih unggul dibanding \\
Lingkungan & rendah dibandingkan kota & kota Bandung) \\
\hline
\end{tabular}

Sumber: solopos.com, 2015 
Perkembangan kuliner yang cepat di Bandung membuat masyarakat menjadi sulit untuk menentukan tempat makan apa yang akan dituju. Dengan adanya media sosial Instagram ini, memudahkan masyarakat untuk mencari informasi kuliner di kota Bandung dengan mudah. Saat ini banyak bermunculan akun Instagram yang khusus memposting foto dan informasi tentang kuliner di kota Bandung, bahkan memiliki followers hingga ribuan. Banyaknya followers di dalam salah satu akun Instagram dapat memengarui followers lainnya untuk mempercayai akun tersebut. Tabel 2 adalah 3 akun yang menyuguhkan informasi tentang kuliner di kota Bandung.

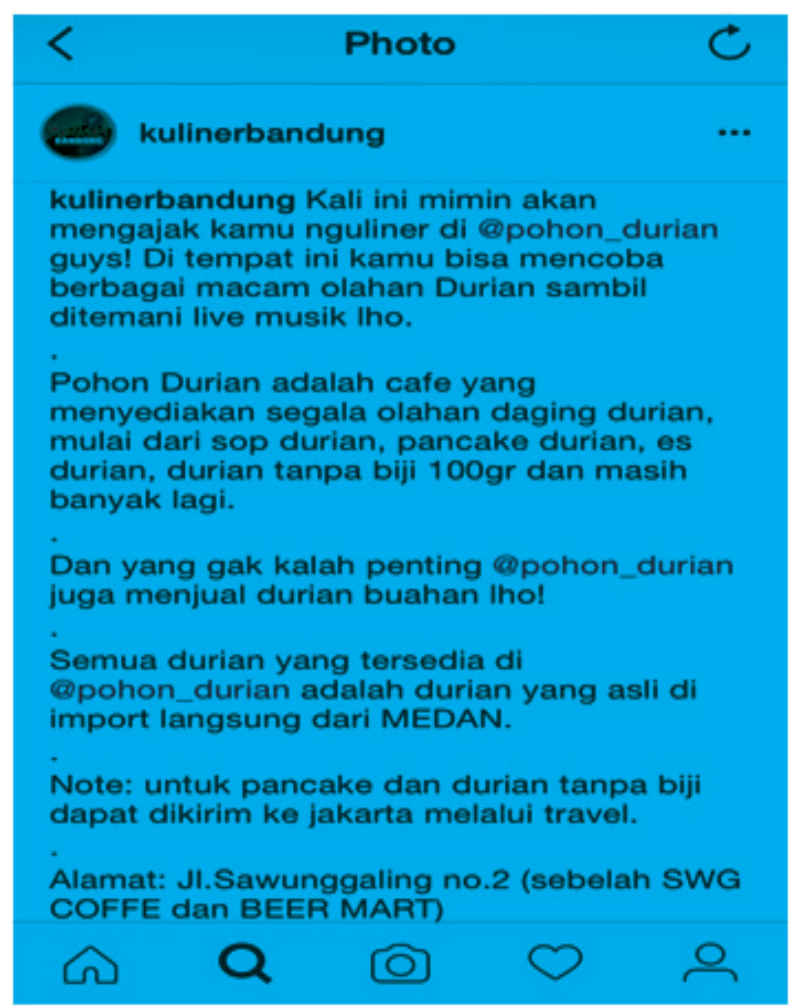

Sumber: Dok penulis, 2016

Gambar 4 Caption Instagram Akun @ Kulinerbandung
Salah satu akun kuliner di Bandung dengan followers terbanyak adalah@kulinerbandung, akun ini memiliki lebih dari 390.000 followers, dengan postingan foto sebanyak 562 (terhitung tanggal 14 September 2016). Akun ini menjadi daya tarik tersendiri untuk diteliti. Penulisan karakter atau caption di instagram yaitu berjumlah 2200 ini memudahkan kita untuk bisa lebih banyak memberikan informasi kepada followers kita, sama halnya yang dimanfaatkan oleh@kulinerbandung. Akun ini memberikan informasi tentang sebuah rumah makan dengan kata kata yang menarik, mulai informasi tentang alamat, makanan favorit, hingga harga rata rata di rumah makan tersebut. Salah satu kunci agar memiliki akun dengan followers yang banyak dan berkualitas adalah dengan menulis caption yang menarik. Gambar 4 adalah contoh caption yang dibuat oleh@kulinerbandung yang memberikan informasi tentang rumah makan bernuansa durian.

Akun@kulinerbandungjugamenambahkan sebuah hashtag (tanda pagar atau \#) di dalam caption-nya. Hashtag di Instagram digunakan untuk mempermudah pengelompokan konten, agar sebuah konten dicari dengan mudah, agar sebuah postingan dapat dilihat lebih banyak agar tidak hanya followers yang melihat, dan bahkan hashtag sekarang digunakan untuk menambah followers dan media promosi. Kita pun bisa me-klik hashtag tersebut, lalu kita akan dibawa 
Tabel 2 Tiga Akun Kuliner di kota Bandung dengan Followers Terbanyak

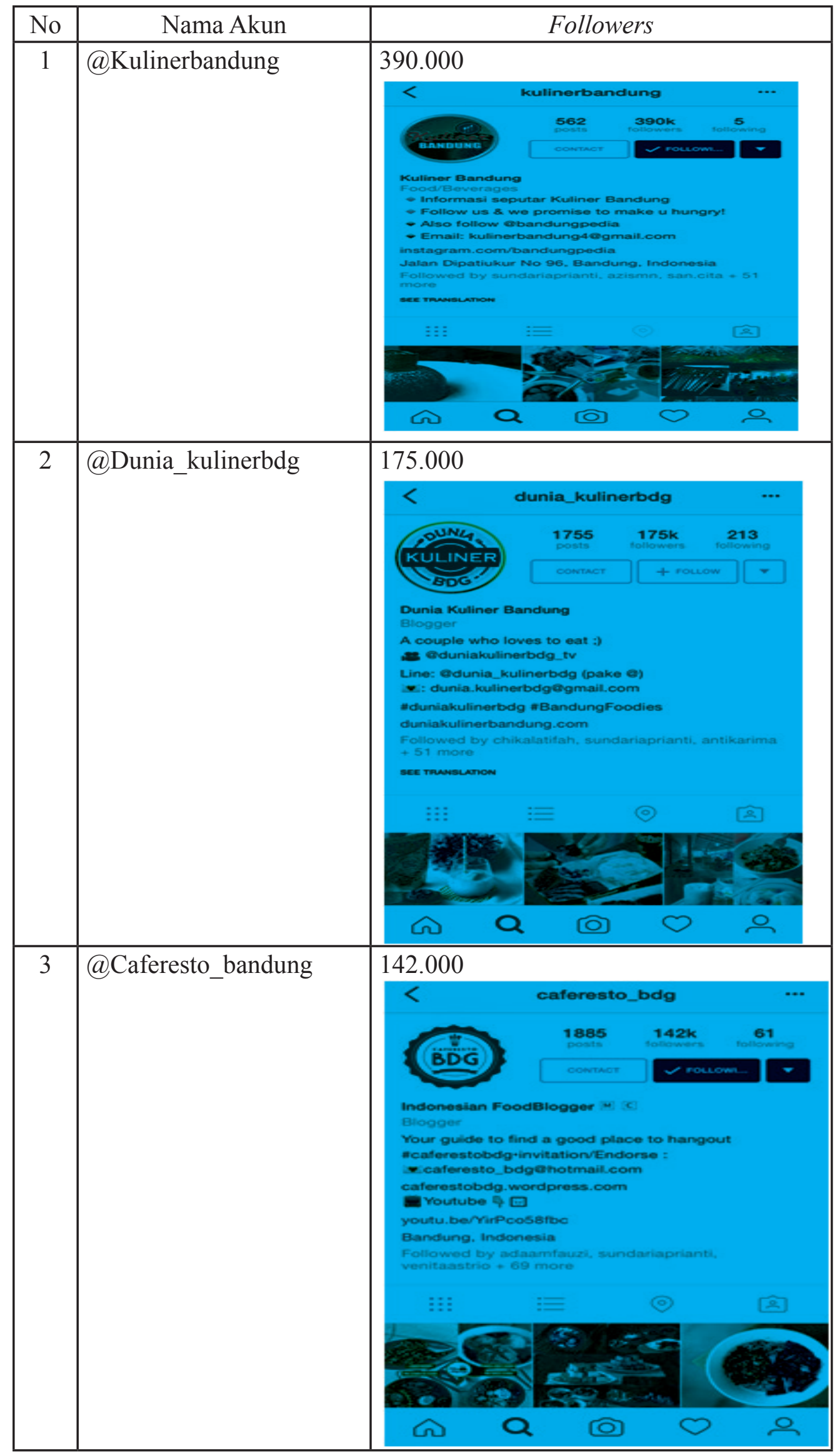

Sumber: Hasil penelitian, 20

Penggunaan Akun Instagram Sebagai Media Informasi Wisata Kuliner (Difa Nurhasna Ayutiani dan Berlian Primadani Satria Putri) 
kepada postingan yang serupa dengan hashtag tersebut. Akun Instagram @Kulinerbandung membuat hashtag yang sangat sesuai dengan konten fotonya. Gambar 5 adalah contoh hashtag yang dibuat oleh@Kulinerbandung.

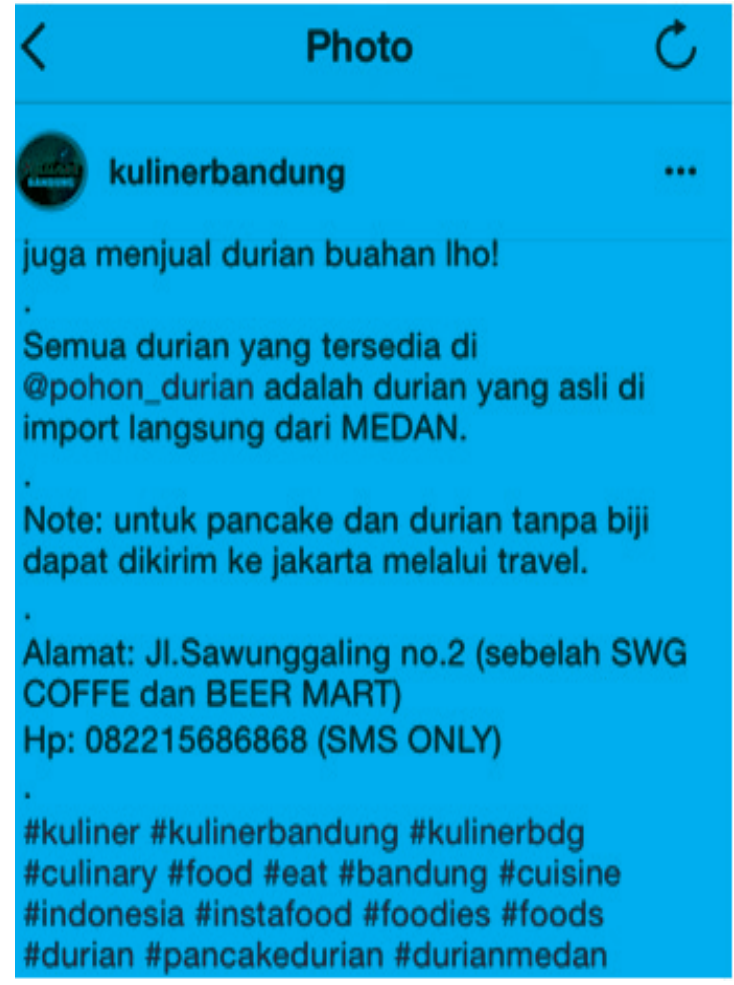

Sumber: Dok. Penulis, 2016

\section{Gambar 5 Penggunaan Hashtag Pada Akun}

\section{@Kulinerbandung}

@ kulinerbandung juga memiliki akun media sosial lainnya yaitu Twitter yang memiliki followers lebih banyak dibanding Instagramnya, yaitu 580 ribu. Penulisan tweet yang hanya 140 karakter di Twitter membuat kurangnya informasi dan followers lebih memilih Instagram dibanding Twitter @ kulinerbandung.

Hal ini terlihat dari keaktifan followers nya menanggapi tweet dari@kulinerbandung yang tweet-nya hanya di re-tweet oleh rata rata 6-10 orang saja saat ini. Maka dari itu masyarakat saat ini sangat menyukai media sosial Instagram dibandingan dengan media sosial lainnya dalam memilih media informasinya. Dibawah ini adalah akun twitter milik@Kulinerbandung:

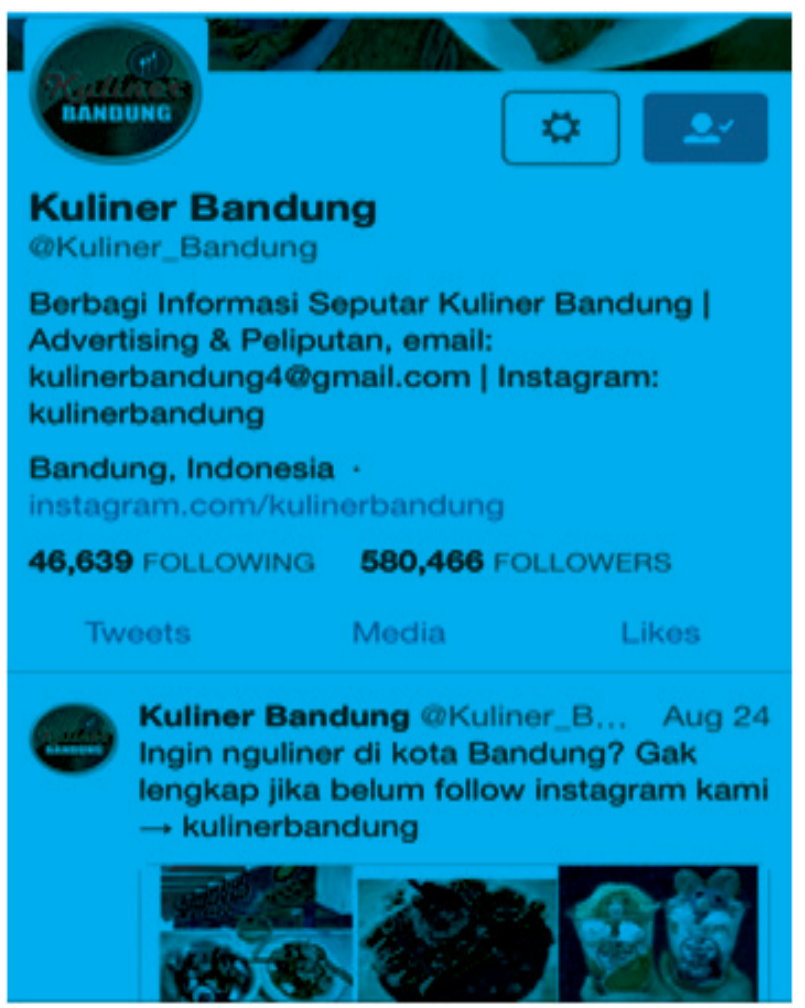

Sumber: Dok. Penulis, 2016

Gambar 6 Akun Twitter Milik @ Kulinerbandung

Walaupun followers Twitter @ kulinerbandung lebih banyak dibandingkan followers di Instagram, tetapi saat ini masyarakat lebih memilih media Instagram dibandingkan media sosial Twitter, dikutip dari situs The Verge, Chief Executive Officer (CEO) Kevin Systrom mengatakan jumlah pengguna aktif Instagram sekarang berjumlah 300 juta 
orang. Jumlah ini lebih banyak dari Twitter yang hanya sebesar 284 juta orang pengguna. Bila dibandingkan dengan pertumbuhan jumlah penguna aktif Instagram dan Twitter dalam kurang satu tahun terakhir, Instagram lebih cepat tumbuh dibanding Twitter. Pengguna Twitter di akhir tahun 2012 mencapai 200 juta, tetapi pertumbuhannya terus menurun sejak saat itu. Lalu, pengguna Instagram baru mencapai 150 juta pada bulan September 2013, tapi sekarang jumlah penggunanya lebih banyak dibanding Twitter.

Menurut survei yang dilakukan oleh TNS, sebuah lembaga riset dari Inggris, 59\% pengguna Instagram di Indonesia adalah 1824 tahun dan diantaranya adalah perempuan (Beritagar.id). Kemunculan Instagram membuat masyarakat di Bandung cenderung lebih sering mencari informasi melalui aplikasi media sosial Instagram melalui handphone dan membuat perubahan sosial kepada penggunanya dalam gaya hidup berwisata kuliner.

Kebiasaan masyarakat di Bandung yaitu hangout dengan teman-temannya dan mencicipi kuliner ini membuat mereka sangat aktif untuk mencari informasi kuliner di kota Bandung. Akun@Kulinerbandung telah menjadi sebuah sumber informasi bagi para followers-nya, GAMBAR 7 adalah 4 komentar yang ditulis oleh para followers di akun@Kulinerbandung di beberapa postingannya.

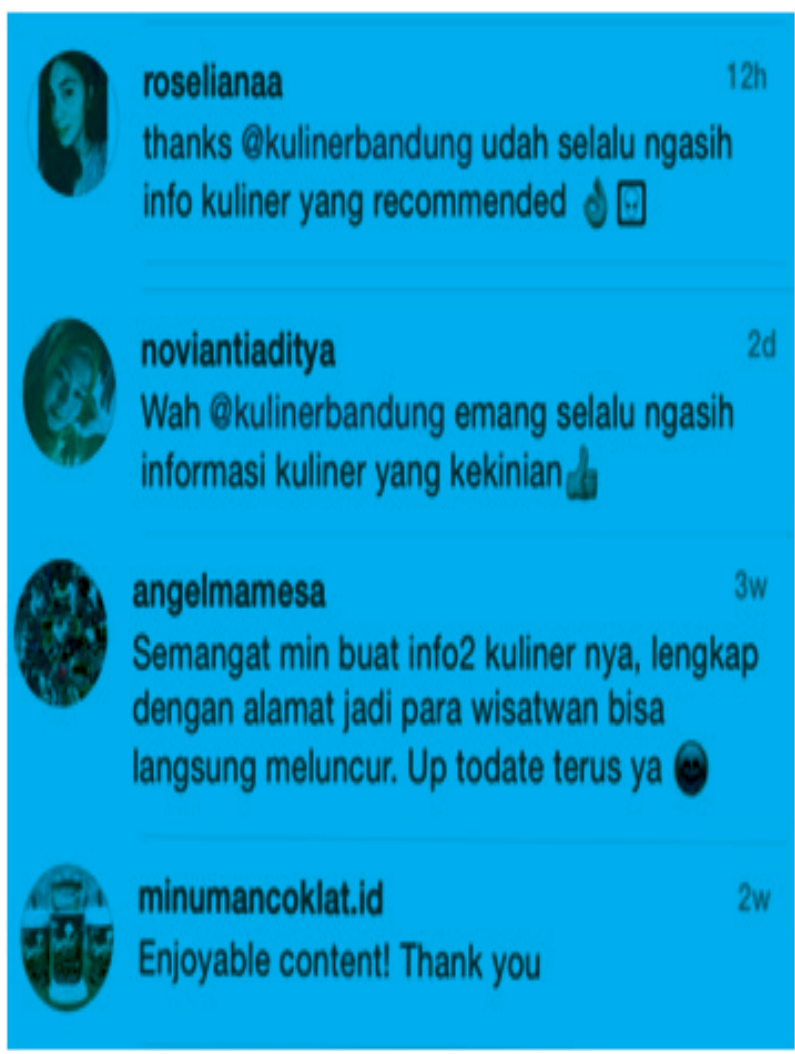

Sumber: Dok. Penulis, 2016

Gambar 7 Komentar followers Akun@ Kulinerbandung

Penggunaan media sosial Instagram sebagai media informasi untuk mencari kuliner di Kota Bandung oleh followers ini menghasilkan sebuah respons kognitif (informasi), afektif (emosi) dan behavioral (tindakan) dalam mengakses, melihat, dan mencari postingan akun@Kulinerbandung. Respons followers yang berbeda-beda ini membuat penulis tertarik untuk meneliti dan merumuskan masalah ini ke dalam judul: "Penggunaan Akun Instagram sebagai Media Informasi Wisata Kuliner (Studi Virtual Etnografi pada Followers Akun@ Kulinerbandung)". 


\section{METODE PENELITIAN}

Penelitian ini menggunakan metode kualitatif. Metode ini adalah metode yang digunakan untuk meneliti seseorang dengan cara yang alamiah, sebagai lawannya adalah eksperimen, dimana peneliti berposisi sebagai instrumen kunci, teknik pengumpulan data dilakukan secara triangulasi (gabungan), analisis data yang bersifat induktif, dan hasil penelitian kualitatif akan lebih mengarah kepada kegiatan yang alamiah atau natural setting. Maka dari itu metode ini sering disebut sebagai metode naturistik. Data yang pasti adalah data yang sebenarnya terjadi apa adanya, tidak hanya data yang cukup terlihat dan terucapkan tetapi data yang mengandung berbagai makna di balik yang terlihat dan terucap tersebut. Metode kualitatif digunakan untuk mendapatkan data yang mendalam, sebuah data yang mengandung makna. Makna adalah data yang sebenarnya, data yang pasti yang merupakan suatu nilai di balik data yang tampak (Sugiyono, 2014: 1). Creswell (2012: 16) menyebutkan ada enam karakteristik penelitian kualitatif yang bisa terlihat dari segi tahapan penelitian sebagai berikut. (1) mengeksplorasi suatu masalah dan mengembangkan sebuah pemahaman yang detail tentang sebuah tema utama. (2) memiliki tinjauan literatur yang memainkan peranan kecil (minor), tetapi menjustifikasi masalah. (3) menentukan tujuan dan pertanyaan-pertanyaan penelitian dalam cara yang umum dan luas mengenai pengalaman-pengalaman partisipan. (4) mengumpulkan berdasarkan pada kata-kata dari sejumlah kecil individu sehingga pandangan partisipan diperoleh. (5) meganalisis data untuk deskripsi dan tema-tema dengan mengunakan analisis teks dan menginterprestasi makna yang lebih besar tentang temuan-temuan. (6) menulis laporan dengan menggunakan struktur-sktuktur yang darurat, fleksibel dan mengevaluasi kriteria, dan termasuk efektivitas subjektif dan bias.

Penelitian ini menggunakan metode kualitatif Virtual etnografi. Menurut Nasrullah (2015: 171) metode etnografi dilakukan untuk melihat fenomena spsial dan kultur dari pengguna di ruang siber. Menurut Bell, metode etnografi adalah metode yang paling utama dalam melihat fenomena budaya siber di Internet. Jadi, kajian virtual etnografi adalah sebuah pola pendekatan penelitian terhadap internet yang dilakukan tergantung bagaimana individu -individu itu menanggapinya. Budaya yang terdapat di dalam sebuah Internet bisa diperluas dengan menggunakan perspektif etnografi melalui konstusi teknologi dalam konteks fenomena sosial budaya yang terkandung di dalamnya. Dengan menggunakan metode virtual etnografi peneliti meneliti kultur yang terjadi di suatu komunitas atau berada di 
tempat yang pasti. Peneliti etnografi merekam jejak, mendengar sebuah perbincangan dan membongkar sebuah dokumen untuk studi yang dilakukan. Artinya peneliti etnografi berada di tengah-tengah sebuah komunitas, melihat sendiri secara langsung penelitian, dan berbicara atau mewawancarai langsung informannya. Dalam penelitian virtual etnografi ini, keberadaan peneliti, subjek peneliti dan lokasi penelitian itu harus terjadi secara real. Jadi pada penelitian kali ini, penulis tidak hanya mengamati informan melalui media siber atau akun Instagram milik informan, tetapi penulis juga meneliti dengan cara bertemu langsung secara fisik danmewawancaraimereka. Christine Hine (dalam Arif, 2012: 172) menyebutkan adanya 10 prinsip virtual etnografi, yaitu: 1). etnografi virtual mempertanyakan asumsi yang sudah berlaku secara umum tentang Internet. Oleh karena itu peneliti hendaknya menginterpretasikan sekaligus reinterpretasi Internet sebagai sebuah cara sekaligus medium yang digunakan untuk berkomunikasi. 2). berbeda dengan kehidupan nyata dan fenomena yang muncul dari interaksi face-to-face, Internet merupakan lapangan yang sangat kompleks dan relasi yang terjadi berdasarkan pada konteks apa yang digunakan termasuk terhadap penggunaan teknologi. Sehingga ketika meneliti Internet, maka semestinya menempatkan Internet sebagai sebuah kultur dan artefak cultural. 3).
Internet mengubah pemahaman tentang 'lokasi' penelitian. Internet adalah tempat yang interaktif dan selalu bergerak sehingga lebih tepat dalam pendekatan etnografi untuk melihat bagaimana tempat virtual di Internet itu dibuat dan dibuat kembali. 4). konsekuensi dari gagasan tentang 'lokasi' tersebut memunculkan pertanyaan yang serius. Sebab, dalam etnografi kultur serta komunitas bisa diidentifikasikan dalam lapangan atau lokasi yang nyata. Hine menawarkan solusi bahwa penelitian dilepas pisahkan dari pemahamam umum terhadap lokasi dan batas-batas, melainkan memfokuskan diri pada arus dan koneksitas antar-user di Internet. 5). etnografi virtual pada dasarnya juga mengangkat persoalan batas-batas, akan tetapi konteks tersebut untuk melihat kenyataan antara yang 'real' dengan 'virtual'. 6). etnografi virtual merupakan persinggahan sementara. Kehidupan pengguna di Internet tidak terjadi dalam 24 jam yang sesunguhnya, netter atau pengguna internet tidak dapat dipastikan kapan mereka "berada" di internet. 7). dalam etnografi virtual fenomena yang diangkat merupakan kepingan-kepingan semata, tidak menggambarkan bagaimana sesungguhnya kehidupan di Internet itu berlangsung. Bagi Hine, ada kerumitan dalam hal menjangkau informan, lokasi dan bahkan kultur itu sendiri secara seutuhnya. 8). etnografer hendaknya mereka yang juga menjadi bagian dalam 
cyberspace. Hubungan antara etnografer dengan subjek atau objek penelitian yang menggunakan teknologi merupakan bagian dari pengalaman pribadi etnografer ketika bersentuhan dengan (teknologi) Internet dan menjadi bagian dalam cyberspace harus diabaikan demi menjaga objektivitas dalam melihat fenomena. 9). etnografer maupun informan (penelitian) harus dirasakan kehadiran antar keduanya. Etnografi virtual dijelaskan sebagai "ethnography in, of and trough the virtual" sehingga interaksi tatap muka atau face to face tidak diperlukan 10). beberapa terminologi, prinsip, maupun aturan yang selama ini dipahami dalam etnografi, pada dasarnya tidak bisa diterapkan dalam etnografi virtual. Bahkan ketika membahas kata 'virtual' pun definisi ini menemukan bentuk dan keluaran yang tidak terduga. Oleh karena itu, ketika meneliti cyberculture maka konteks yang digunakan sebisa mungkin merupakan kondisi yang mendekati 'apa yang terjadi' di cyberspace dan bisa digunakan dalam tataran praktis untuk mengeksplorasi relasi yang terjadi melalui media Internet yang ditemui oleh etnografer.

\section{HASIL DAN PEMBAHASAN}

Hasil penelitian yang didapat oleh penulis dalam penelitian yang merupakan interpretasi dari hasil penelitian melalui teknik wawancara, observasi dan data dokumentasi ini didapat dari empat orang followers akun@Kulinerbandung yang berdomisili di kota Bandung. Pembahasan penelitian ini dijelaskan dengan menggunakan tinjauan teori dan konsep yang telah dibahas sebelumnya.

Respons diartikan sebagai suatu hasil atau akibat yang dikerjakan oleh seseorang yang menerima sebuah stimulus. Stimulus ini merupakan sesuatu yang dapat diterima seseorang melalui alat inderanya. Terdapat tiga respons, yang dikemukakan oleh Steven M. Chaffee (Rakhmat, 1999: 118) yang pertama adalah respons kognitif, berkaitan dengan pengetahuan, keterampilan dan informasi seseorang mengenai sesuatu yang timbul bila dipahami atau digambarkan oleh seseorang. Jadi respons kognitif diartikan juga sebagai respons yang membahas tentang sebuah kebiasaan dalam mencari berbagai pengetahuan dan informasi oleh seseorang mengenai sesuatu yang bisa membentuk suatu makna dan pandangan. Hal tersebut bila dikaitkan dengan kegiatan followers@Kulinerbandung yang mencari informasi kuliner melalui akun tersebut. Pemililihan media informasi saat ini sangat diperlukan. Pengguna media memiliki peran aktif untuk memilih dan menggunakan suatu media. Biasanya para pengguna media memilih suatu media karena kebutuhan secara psikologis dan sosial masing-masing. Sama halnya dengan yang dilakukan oleh informan, mereka memilih Instagram sebagai seperangkat 
media informasi kulinernya dikarenakan pengaplikasiannya yang mudah, banyaknya penguna Instagram dan lengkapnya fitur atau konten yang ditawarkan. Islaminur Pempasa seorang ahli di bidang komunikasi mengatakan bahwa alasan pengguna media menggunakan Instagram untuk mencari informasi, yang pertama bisa dilihat dari segi kemudahan, dan pada kajian komunikasi ada sebuah teori yang bernama uses and gratification, Teori ini pertama kali dikenalkan oleh Harbert Blumer dan Elihu Katz (1974). Teori ini membahas bahwa pengguna media memainkan peran aktif untuk memilih dan menggunakan media tersebut. Yang artinya, pengguna media adalah pihak yang aktif dalam proses komunikasi (Hidayat, 2006: 192). Uses and gratifications meneliti asal mula kebutuhan secara psikologis dan sosial, yang menimbulkan harapan tertentu dari media massa atau sumber-sumber lain, yang membawa pada pola terpaan media yang berlainan, dan menimbulkan pemenuhan kebutuhan dan akibat-akibat lain.

Setelah masuk ke wilayah digital ini, banyak manfaat dan kemudahan bagi pengguna teknologi untuk mengakses informasi, pengetahuan, dan rujukan mereka untuk memilih media dalam satu alat, yang ada di tangan mereka, dapat memberikan manfaat dan menggabungkan berbagai platform informasi sehigga menjadi lebih mudah. Kelebihan fitur dari Instagram kuliner, yang tidak melulu text, harus ditambah dengan foto, audio dan video cara pembuatan, akhirnya seseorang pun memilih sumber informasi yang lengkap dan kaya informasi. Banyaknya followers di suatu akun kulinerpun membuat orang percaya akan akun tersebut dan dapat dipercaya untuk dijadikan media informasi kuliner. Dikutip dari websitedailysocial.id, sebuah data yang dihimpun AdParlor, Instagram masih menjadi media sosial yang disukai oleh kaum muda dengan angka yang cukup besar yakni $40 \%$. Dan hal ini sesuai dengan hasil penelitian dari Rumyeni, Lubis, dan Yohana (2015) yang menyatakan bahwa mayoritas kaum muda mengakses media sosial adalah melalui telepon seluler atau smartphone. Angka ini terhitung besar dan merupakan wadah bagi para marketers. Alasan terbesar mengapa kaum yang ada di wadah ini memilih Instagram adalah karena daya tarik, keseruan, dan tren yang berkembang di dalamnya. Adanya pengalaman yang menyenangkan, Instagram menyuguhkan konten-konten yang secara estetika menyenangkan bagi audiens. Hal tersebut yang menurut sebuah studi, membuat kaum mudadi Instagram loyal terhadap brand dan korporasi yang sudah mengimplementasikan content marketing di sana.

Keempat informan dalam penelitian ini menyatakan bahwa mereka ingin mencari 
informasi tentang kuliner di kota Bandung melaluiakun@Kulinerbandung,danmerekapun akhirnya mem-follow akun ini dan menjadikan postingannya sebagai referensi dalam berwisata kuliner. Para followers@Kulinerbandung juga mendapatkan manfaat dari mem-follow akun ini. Manfaat yang diterima berupa informasi terbaru tentang kuliner yang didapatkan melalui postingan akun@Kulinerbandung. Manfaat yang didapatkan oleh mereka termasuk kedalam efek proposial kognitif media, yaitu bagaimana media Instagram dapat membantu khalayak mempelajari informasi yang bermanfaat dan mengembangkan keterampilan kognitifnya (Rakhmat, 2011: 221). Pak Ipe juga setuju bahwa akun@Kulinerbandung memberikan manfaat yang didapatkan oleh followers akun @ Kulinerbandung dan juga banyaknya followers di akun tersebut sangat memengaruhi seseorang dalam memilih media informasi apa yang digunakan mereka dalam mencari referensi makanan.

Para informan juga mengetahui akun@ Kulinerbandung adalah akun kuliner yang memiliki paling banyak followers di kota Bandung dan menjadikannya alasan dalam memilih akun tersebut dalam mencari informasi kuliner. Seperti apa yang dikatakan oleh Pak Ipe, semakin banyak followers, seseorang pun menjadi ingin tau dan terlibat di dunia nyata dan maupun di dunia virtual ini. Istilah ini disebut konsosial, artinya share yang orang berikan dan yang kita beri. Informasi yang diterima oleh followers setelah melihat postingan berisi informasi kuliner melalui akun@Kulinerbandung adalah salah satu cara kita mengorganisasikan citra terhadap suatu lingkungan. Lengkap atau tidaknya suatu informasi memengaruhi para followers dalam memenuhi kebutuhannya. Akun @ Kulinerbandung memberikan informasi cukup lengkap melalui caption yang dibuatnya, menurut informan, akun ini biasanya menampilkan harga, jam buka tempat makan, komposisi makanan yang ditawarkan oleh suatu tempat makan, hingga sapaan yang menarik. Foto yang diposting juga sangat menarik dan informatif bagi follower-nya. Salah satu informan menyebutkan bahwa:

"foto dan caption yang informatif di dunia digital pada generasi virtual saat ini sangat dibutuhkan agar orang-orang tertarik kepada isi akun tersebut, maka dari itu Instagram menolong dalam mendapatkan informasi, dan akun @Kulinerbandung sudah memasuki kriteria media yang memberikan informasi tentang kuliner" (Wawancara dengan Ipe, 2016).

Respons yang kedua adalah afektif, respons ini adalah suatu perubahan dan pembentukan sikap seseorang yang melibatkan suatu rangsangan emosional atau mood, terdapat beberapa faktor yang memengaruhi intensitas rangsangan emosional, salah satunya adalah suasana emosional atau kondisi individu secara 
psikologis yang ada ketika ia mengkonsumsi media (Mutmainah dan A. Fauzi, 2002). Pada respons ini, penulis ingin mengetahui apakah followers setelah melihat postingan dari akun@Kulinerbandung merasakan adanya rasa ketertarikan dan ingin selalu datang ke tempat yang direkomendasikannya. Dari hasil wawancara terdapat hasil yaitu adanya perbedaan mood dan kebutuhan followers dalam ketertarikannya untuk datang ke suatu tempat yang direkomendasikan.

"Foto, tulisan dan share itu yang membuat menarik. Apalagi semuanya itu sudah memenuhi kebutuhan followers. Sikap dan emosional followers dalam menanggapi postingannya tergantung dari bagaimana kebutuhan followers tersebut dan juga kepercayaan mereka terhadap akun yang mereka jadikan referensi kuliner" (Wawancara dengan Ipe, 2016).

Sikap emosional lainnya ditunjukkan followers saat mereka menyukai sesuatu hal yang diberikan oleh@Kulinerbandung, contohnya melalui foto dan caption-nya. Setiap followers akan mempersepsikan pendapatnya terhadap postingan yang disajikan oleh akun@Kulinerbandung. Pak Ipe pun memberikan pendapatnya tentang isi konten @Kulinerbandung yaitu hasil foto yang sudah memenuhi syarat dan menggunakan cara profesional. Banyaknya likers dalam satu postingan akun@Kulinerbandung juga membuat seseorang menjadi ingin datang ke tempat yang direkomendasikan akun tersebut.
Tampilan foto sangat memengarui seseorang untuk mengakses suatu akun kuliner untuk mencari informasi, karena menurut Pak Ipe, hal tersebut adalah standar teknik promosi membuat orang tertarik dan menjadi jembatan bagi produsen agar produknya dipromosikan. Maka dari itu, melalui pendapat pak Ipe, followers merasakan adanya kesukaan dan ketidaksukaan mereka terhadap postingan akun @Kulinerbandung.

Hal itu menandakan adanya perubahan sikap emosional terhadap para followers saat melihat postingan@Kulinerbandung. Segala perubahan sikap tersebut juga dikendalikan oleh bagaimanalatarbelakang atau faktorpredisposisi individualnya yang mengacu terhadap karakter khas individunya dan bagaimana setiap individu tersebut mendapatkan informasi yang akhirnya merubah dan pembentukan sikap, dan respons yang terakhir yaitu behavioral, respons ini adalah akibat yang ditimbulkan oleh diri khalayak yang membentuk sebuah perilaku, tindakan dan kegiatan. Terdapat dua efek media yang menghasilkan sebuah respons behavioral yaitu perilaku agresif yaitu kegiatan yang buruk bahkan merusak dan perilaku proposial atau kegiatan yang bersifat positif (Mutmainah dan A. Fauzi, 2002). Pada kegiatan followers untuk mencari informasi kuliner pada akun@Kulinerbandung, terdapat perilaku proposial atau adanya kegiatan postitif setelah 
mendapatkan informasi. Kegiatan ini merancu kepada hal yang menimbulkan keterampilan yang bermanfaat bagi dirinya sendiri bahkan untuk orang lain.

Kegiatan postitif yaitu para followers melakukan kegiatan berkuliner dengan mencari informasi di akun@Kulinerbandung. Kegiatan berkuliner ini ada karena sebuah hasil dari faktor kognitif atau proses belajar dan lingkungannya.

Setelah melewati proses belajar, informan melakukan kegiatan berwisata kuliner melalui referensi melalui akun@Kulinerbandung. Para followers yang sudah memiliki hobi berkuliner sebelum adanya akun@Kulinerbandung ini, merasakan adanya pertambahan intensitas berkuliner dikarenakan mereka menjadi lebih mudah dalam mencari informasi tempat makan di kota Bandung. Pak Ipe pun merasakan hal yang sama, ia menjadi sering mengakses akun kuliner saat ia mencari tempat makan.

Kegiatan followers untuk selalu mendapatkan informasi ini biasanya dilakukan mereka tidak hanya pada saat mereka membutuhkannya, tetapi di waktu senggangnya mereka juga dengan sengaja men-searching tempat makan untuk referensi kuliner mereka selanjutnya, apalagi informasi yang diberikan oleh akun@Kulinerbandung di update setiap harinya. Kegiatan ini masuk ke dalam kebutuhan informasi menurut Guha yaitu exhaustic need approach, yaitu kebutuhan para pengguna yang ingin mendapatkan informasi yang mendalam, pengguna informasi pun menjadi ketergantungan yang tinggi akan informasi yang dibutuhkannya. Biasanya jenis informasi yang dibutuhkan bersifat relevan, spesifik, dan lengkap.

Kegiatan berkuliner tentunya akan mengeluarkan biaya bahkan menghasilkan sifat konsumtif, tetapi hal ini kurang dirasakan oleh keempat informan. Sebagian dari informan hanya merasakan adanya alokasi budget khusus untuk berkuliner, hal ini dikemukakan oleh pak Ipe bahwa ada perubahan perilaku dan gaya hidup, di kota-kota besar. Kebiasaan masyarakat yang hidup di kota besar yang terbiasa sibuk dan melakukan kegiatan di luar rumah akan merubah gaya hidupnya. Gaya hidup ini merubah seseorang yang memungkinkan bisnis kuliner berkembang dan banyaknya kulineryang baru. Daya tarik kerumunan juga memengaruhi seseorang bila ingin mendatangi suatu tempat kuliner. Seseorang pun menjadi merubah gaya hidupnya menjadi menyukai kuliner bahkan memiliki alokasi dana khusus.

Kegiatan mencari informasi ini juga diinginkan oleh followers untuk menjadikan dirinya sebagai sumber informasi bagi temantemannya dan dianggap paling mengetahui kuliner, hal ini dianggap pak Ipe sebagai hal yang wajar, dan juga beberapa orang ingin dianggap sebagai pakar dan ahli dalam berkuliner. Bila 
kita men-share foto kita dapat mendefinisikan diri kita sesuai dengan apa yang kita share di media sosial kita. Terkait dengan teori identitas, kita dalam media sosial belum tentu seperti apa adanya. Pak Ipe pun menganalogikan walaupun tidak suka berkulier, tapi seseorang yang menyukai kegiatan fotografi, maka tidak memungkiri bahwa mereka akan men-share foto makanan dan akan dianggap sebagai seseorang yang mengetahui informasi kuliner.

Pak Ipe sendiri pun merasakan adanya keinginan menjadi orang yang mengetahui segala kuliner di kota Bandung, Keinginan menjadi sumber informasi ini dikarenakan pak Ipe tidak ingin ketinggalan berita dan selalu update tentang kuliner di kota Bandung, bahkan kota lainnya.

Salah satu informasi yang diberikan oleh akun@Kulinerbandung adalah adanya postingan berupa promosi dan diskon dari suatu tempat makan. Postingan ini belum tentu ada di setiap akun kuliner lainnya. Para informan mengetahui adanya postingan berisi promosi dan diskon dari suatu tempat makan, mereka juga cukup tertarik dan ingin datang ke tempat makan itu setelah melihat postingan akun tersebut. Menurut pak Ipe:

"Bila dilihat ada tiga bentuk yaitu yang pertama adalah terdapat foto dan teks biasa yang menawarkan menu, yang kedua adalah bentuk promosi dan ketiga menyangkut kuliner lain pada postingan akun@Kulinerbandung” (Wawancara dengan Ipe, 2016).
Artinya terdapat strategi spesifik untuk menarik massa langsung di promosi yang bersifat medium dan yang mengumpulkan massa. Hal ini adalah strategi bagus agar massa dapat berkumpul.Untuk menghindari kesalahan informasi, sebagai pengguna media kita harus mencari informasi tidak hanya melalui satu media saja, Pak Ipe mengemukakan bahwa, media sosial Instagram sangat cukup untuk mencari informasi tentang kuliner, dan apabila kita menginginkan informasi lebih dari sekedar alamat, lokasi dan foto dari suatu tempat makan yang direkomendasikan, kita bisa mencari informasi di media lainnya. Pak Ipe juga menambahkan bahwa kebutuhan informasi setiap orang berbeda-beda, terlihat dari wawancara keempat informan yang ternyata lebih memilih Instagram dibidang media lainnya dan tidak hanya mencari informasi di akun@Kulinerbandung saja, tetapi mereka melihat referensi melalui akun kuliner lainnya.

Cara followers untuk memberikan informasi kepada teman-temannya berbedabeda, mulai dari me-mention temannya pada kolom komentar di akun kuliner, membuat Instgaram story, memposting foto di akun pribadinya hingga membuat akun kuliner. Pertama, para followers untuk memberikan informasi adalah me-mention temannya pada kolom komentar suatu postingan, hal 
ini menurut pak Ipe adalah kelebihan media sosial saat ini, apalagi Instagram memiliki fitur ini dan memudahkan kita berbagi informasi dengan pengguna akun lainnya. Menurut pak Ipe, adanya fitur komentar dapat memudahkan penggunanya dalam berbagi informasi dengan teman-temannya, hal ini juga yang dirasakan oleh informan sebagai pengakses akun @ Kulinerbandung.

Kedua, yaitu membuat Instagram story. Fitur terbaru ini muncul di pertengahan tahun 2016. Fitur ini memungkinkan kita memposting foto atau video keseharian kita yang hanya dapat dilihatdalam waktu 24 jam saja. Setelah melewati 24 jam, postingan story kita akan terhapus dengan sendirinya. Fitur ini dimanfaatkan oleh informan untuk menginformasikan makanan apa yang sedang mereka santap, bahkan cara pembuatan makanan tersebut mereka posting. Hal ini dikemukakan oleh pak Ipe yang mengatakan bahwa Instagram story adalah cara baru untuk kita menginformasikan kuliner yang sedang mereka makan dan masuk ke dalam sebuah pembentukan identitas pada akun@ Kulinerbandung. Kegiatan yang terakhir adalah memposting foto makanan hingga menandai akun-akun kuliner. Kegiatan yang cukup sering dilakukan oleh followers adalah memposting foto makanan di akun pribadinya, agar temantemannya mengetahui makanan apa saja yang mereka santap. Beberapa followers biasanya men-tag atau menandai akun kuliner di postingannya. Pak Ipe mengomentari bahwa: "Hal ini biasanya termasuk kedalam teknik promosi, kita di awarkan apabila kita metag kita dapat diskon atau kita dapet kartu member penting untuk promosi, itu dapet semacam simpul agar temen-temennya lihat, nah itu bentuknya promosi. kita hanya cukup memotret makanan dan di upload ke akun pribadi kita lalu di tag ke akun Instagram yang mengadakan promosi tersebut tetapi kita mendapatkan untung yaitu diskon, terus tempat makan tersebut mendapatkan untung promosi, dan hasil foto kita mendapatkan like bahkan di repost oleh akun yang ia tag tersebut" (Wawancara dengan Ipe, 2016).

Kegiatan yang tidak banyak dilakukan oleh followers lainnya adalah seorang informan bernama Rohmah, ia melihat kekurangan akun @Kulinerbandung yang hanya berfokus pada makanannya, sedangkan para followers juga ingin mengetahui bagaimana bentuk, kapasitas dan interior dari suatu tempat makan. Rohmah juga ingin membuat akun yang tidak hanya berisi makanan, tetapi tempat hiburan seperti tempat bermain keluarga yang ada di kota Bandung. Rohmah pun langsung membuat akun kuliner dan liburan bernama@Happywanderer.id

"Nah namanya aja Happy Wanderer, jadi pengennya seneng seneng kemana aja, makanan dan liburan kemana. Pengennya sih nampilin tempat yang belom di liput. Dan sekarang ga jalan akunnya, aku sih cuma nyumbang foto, temen aku deh yang bikin kata katanya" (Wawancara dengan Rohmah, 16 Desember 2016).

Pak Ipe sangat setuju dengan adanya perilaku yang dibuat seseorang saat mereka 
mengamati sesuatu karena hal tersebut bagian dari dunia virtual saat ini.

"Nah itulah mudahnya melakukan hal di dunia virtual saat ini, maknanya sanget terbuka kita ingin bikin apa juga. Menariknya di etnografi virtual ya itu, kebiasaan baru yang mucul dari seseorang setelah melihat sesuatu, sesuatu ini adalah akun@Kulinerbandung" (Wawancara dengan Ipe, 20 Desember 2016).

Kegiatan berkuliner tentunya akan mengeluarkan biaya bahkan menghasilkan sifat konsumtif, tetapi hal ini kurang dirasakan oleh keempat informan. Sebagian dari informan hanya merasakan adanya alokasi budget khusus untuk berkuliner, hal ini dikemukakan oleh pak Ipe,

"Memang kalo dilihat dari sisi itu ada perubahan perilaku dan gaya hidup, di kota-kota besar kaya di kampung gitu ga ada tekanan waktu, makan santai, pergi ke sawah pulang siang. Sedangkan orang kota ada jarak seperti harus bangun pagi. Jadi maksudnya banyak alokasi makan itu di luar, nah gaya hidup berubah. Gaya hidup ini merubah seseorang yang memungkinkan bisnis kuliner berkembang dan banyaknya kuliner yang baru. Daya tarik kerumunan juga memengaruhi, kok orang-orang udah kesana, aku kok belom, jadi kita tergoda dan terpaksa untuk melakukan alokasi budget" (Wawancara dengan Ipe, 20 Desember 2016).

Dari pernyataan pak Ipe, karakteristik demografis juga menentukan apakah seseorang menjadi merubah gaya hidupnya menjadi menyukai kuliner bahkan memiliki alokasi dana khusus. Disinilah munculnya sebuah etnografi virtual karena adanya kebiasaan atau kegiatan positif yang muncul di dunia Internet saat seseoang melihat postingan akun @ Kulinerbandung.

\section{SIMPULAN}

Setelah dilakukannya wawancara dan observasi, penulis menyimpulkan bahwa adanya respons kognitif pada followers akun @Kulinerbandung mendapatkan informasi dan manfaat yang lengkap tentang kuliner yang ada di kota Bandung dengan postingan yang dikemas secara menarik dan menggugah selera. Kemudahan dalam mengakses akun @)Kulinerbandung di media Instagram juga menjadi pilihan followers untuk mengakses informasi. Kedua adalah adanya respons afektif, para followers ternyata mengalami sikap atau emosi pada dirinya. Perubahan yang terjadi adalah mereka cukup memiliki keinginan untuk mengunjungi tempat yang direferensikan oleh akun@Kulinerbandung dengan ini mereka memulai untuk berkeinginan datang ke tempat makan yang sudah direferensikan oleh @ Kulinerbandung, informan juga mengajak teman-temannya untuk ikut mengunjungi tempat makan tersebut.

Pesan yang disampaikan oleh akun @ Kulinerbandung melalui postingannya yang menarik mulai dari foto dan caption adalah suatu daya tarik untuk followers-nya. Rasa kecewa juga ditimbulkan oleh followers karena 
mereka mengalami sebuah kesalahan pada informasi akun@Kulinerbandung. Pesan yang disampaikan oleh akun@Kulinerbandung melalui postingannya yang menarik mulai dari foto dan caption adalah suatu daya tarik untuk followers-nya. Respons yang ketiga adalah behavioral, hasil respons ini followers pernah berwisata kuliner melalui informasi dari akun@Kulinerbandung, mereka juga biasa menjadwalkan waktu kuliner dan memberikan budget khusus dalam satu minggu untuk hobinya tersebut. Adanya akun @ Kulinerbandung membuat mereka menjadi lebih sering untuk berkuliner, tetapi hal tersebut tidak memunculkan sikap konsumtif. Followers juga memberikan informasi kepada teman-temannya dengan cara me-mention ke akun temannya pada kolom komentar pada postingan@Kulinerbandung yang disukanya kegiatan lainnya adalah memposting foto kuliner bahkan menandai foto tersebut ke akun @ Kulinerbandung dengan harapan foto mereka dapat di like atau re-post, kegiatan terakhir adalah membuat story di Instagram yang berisi tentang kuliner yang sedang disantapnya. Bahkan followers melihat kekurangan dari akun @Kulinerbandung lalu terinspirasi membuat akun wisata dan kuliner yang lebih baik dari sisi kontennya. Maka dari itu informasi wisata kuliner melalui akun@Kulinerbandung telah memberikan respons tindakan kepada followers-nya.

\section{DAFTAR PUSTAKA}

Blumer, H. (1969). Simbolic interactionism: perspective and method. Englewood Cliffs, NJ: Prentice-Hall, Inc.

Creswell, J. W. (2012). Research design pendekatan kualitatif, kuantitatif dan mixed; cetakan ke-2. Yogyakarta: Pustaka Pelajar.

Guha, B. (2004). Documentation and information. World Press: New Delhi.

Gumilar, G. \& Zulfan, I. (2014). Penggunaan media massa dan internet sebagai sarana penyampaian informasi dan promosi oleh pengelola industri kecil dan menengah di bandung. Jurnal Kajian Komunikasi, 2 (1), 85-92.

Hidayat, D. N. (2006). Pengantar komunikasi massa. Rajawali Press: Jakarta.

Ipe. (2016). Personal interview.

Mutmainah, S. \& Fauzi, A. (2002). Psikologi komunikasi. Jakarta: Universitas Terbuka.

Nasrullah, R. (2015). Media sosial, perspektif komunikasi, budaya dan sosioteknologi. Bandung: Simbiosa Rekatama Media.

Putri, S. D. \& Fithrah, D. S. (2017). Pengaruh online marketing campaign \#samyangchallenge terhadap consumer behavior digital natives pengguna youtube Indonesia. Jurnal PRofesi Humas, 1 (2), 132-141.

Rakhmat, J. (1999). Psikologi komunikasi. Bandung: Remaja Rosdakarya.

Rohmah. (2016). Personal interview.

Rumyeni, Lubis, Evawani, E., \& Yohana, N. (2015). Penggunaan media social Facebook sebagai media komunikasi dan interaksi di kalangan siswa sekolah menengah atas negeri 12 kota Pekanbaru. Jurnal Ilmu 
Komunikasi, 6 (2), 113-190.

Sugiyono. (2014). Metode penelitian kuantitatif, kualitatif, dan r\&d. Bandung: Penerbit Alfabeta. 